\title{
Serum endothelin-1 measurement in healthy Maine Coon cats
}

\section{Mensuração de endotelina-1 sérica em gatos sadios da raça Maine Coon}

\author{
Paula Hiromi Itikawa ${ }^{1 *}$; Guilherme Teixeira Goldfeder ${ }^{2}$; \\ Valéria Marinho Costa de Oliveira ${ }^{3}$; Maria Helena Matiko Akao Larsson ${ }^{4}$
}

\begin{abstract}
The plasma concentration of endothelin (ET)-1 increases in human patients with congestive heart failure and is correlated with the degree of hemodynamic and functional changes. An increase in plasma ET-1 concentration is also correlated with cell proliferation, vasoconstriction, hypertrophy of cardiomyocytes and activation of cardiac fibroblasts, all of which are associated with clinical manifestations of heart failure (HF) and pathological remodeling of the heart. Hypertrophic cardiomyopathy (HCM) is the most commonly diagnosed heart disease in cats and is characterized by increased cardiac mass associated with concentric left ventricular hypertrophy (LVH), which is associated with mutations in the cardiac myosin binding protein C (MYBPC3) gene in Maine Coon (MC) cats. ET-1 serum concentrations were measured in 38 healthy MC cats using the human ELISA assay validated for the feline species. Unfortunately, the ET-1 values could not be assessed in the present study because they were above the maximum levels of sensitivity of the test used. ET-1 serum measurements without aprotinin in healthy $\mathrm{MC}$ cats is greater than values ET-1 plasma concentration with aprotinin reported by literature in healthy cats using the Biomedica Endothelin (1-21) diagnosis kit. Using this kit for serum ET-1 measurements without aprotinin in MC cats the dilution of samples is necessary.
\end{abstract}

Key words: Feline, cardiac markers, biomarkers, ET-1, congestive heart failure

\section{Resumo}

A concentração plasmática de endotelina (ET)-1 aumenta em pacientes humanos com insuficiência cardíaca congestiva, sendo correlacionada com o grau de alteração hemodinâmica e funcional e, ainda, com proliferação celular, vasoconstricção, hipertrofia de miócitos cardíacos e ativação de fibroblastos cardíacos, que se associam às manifestações clínicas da insuficiência cardíaca (IC) e ao remodelamento patológico do coração. A cardiomiopatia hipertrófica $(\mathrm{CMH})$ é a doença cardíaca mais diagnosticada em gatos e caracterizada por aumento da massa cardíaca associado à hipertrofia concêntrica do ventrículo esquerdo (HVE) que, em gatos da raça Maine Coon (MC), está associada à mutação do gene da ß-miosina ligada à proteína $\mathrm{C}(\mathrm{MYBPC} 3)$. Foram mensuradas concentrações séricas de ET-1 em 38 gatos sadios da raça MC utilizando ensaio ELISA humano, validado para a espécie felina. Infelizmente, não foi possível determinar os valores de ET-1 no presente estudo, pois estes se encontravam acima dos níveis de sensibilidade do ensaio utilizado. A mensuração sérica de ET-1 sem adição de aprotinina em gatos saudáveis da raça MC são superiores aos valores de concentração plasmática de ET-1 com adição de aprotinina em gatos saudáveis como reportado pela literatura com o kit diagnóstico Biomedica

\footnotetext{
${ }^{1}$ Discente de Doutorado, M.e em Ciências, Faculdade de Medicina Veterinária e Zootecnia, Universidade de São Paulo, USP, São Paulo, SP, Brasil. E-mail: paulaitikawa@gmail.com

2 Veterinário contratado, Faculdade de Medicina Veterinária e Zootecnia da Universidade de São Paulo, USP, São Paulo, SP, Brasil. E-mail: guigagold@hotmail.com

${ }^{3}$ M.e em Ciências, Faculdade de Medicina Veterinária e Zootecnia, USP, São Paulo, SP, Brasil. E-mail: val.mcoliver@globo.com

${ }^{4}$ Prof Titular, Faculdade de Medicina Veterinária e Zootecnia, USP, São Paulo, SP, Brasil. E-mail: akaolar@usp.br

* Author for correspondence
} 
Endothelin (1-21). Ao utilizar esse kit diagnóstico para mensuração sérica de ET-1 sem aprotinina em gatos da raça $\mathrm{MC}$ é necessária a diluição das amostras.

Palavras-chave: Felino, marcadores cardíacos, biomarcadores, ET-1 e insuficiência cardíaca congestiva

\section{Introduction}

Endothelin is a peptide consisting of 21 amino acids, which was identified, isolated and recognized as the most potent vasoconstrictor (YANAGISAWA et al., 1988). The endothelin family consists of three peptides: ET type 1 (ET-1), ET type 2 (ET-2) and ET type 3 (ET-3). ET-1 causes prolonged constriction of medium and large-sized arteries, and the other isoforms also cause vasoconstriction albeit with less potency. ET-1 is synthesized as a pre-prohormone and is cleaved into a 30 -amino acid peptide termed big ET-1. Upon release into the bloodstream, big ET-1 is converted by endothelin converting enzyme into the 21-amino acid active peptide called "mature" ET-1 or simply ET-1 (LEVIN, 1995).

ET-1 is the predominant form of endothelin produced by endothelial cells and cardiomyocytes and has a broad spectrum of action given the presence of receptors of different subtypes including ET receptor subtype A (RET-A), ET receptor subtype $\mathrm{B}$ (RET-B) and ET receptor subtype C (RET-C). Vasoconstriction of smooth muscles, increased myocardial contractility and aldosterone secretion are the main effects mediated by RET-A. Thus, chronic stimulation of RET-A and a persistent increase in ET-1 levels can cause proliferation and vascular smooth muscle hypertrophy of cardiomyocytes, as ET-1 acts as a mitogen responsible for the pathological remodeling of vessels and the heart in response to chronic hypertension and heart failure (HF) (LEVIN, 1995).

ET-1 plasma concentration increases in human patients with chronic heart failure (CHF) and is correlated with the degree of hemodynamic and functional changes (MCMURRAY et al., 1992). Some studies have suggested that endothelin may be a better prognostic indicator than natriuretic peptides (SELVAIS et al., 2000), which are also found at elevated levels in patients with CHF (MCMURRAY et al., 1992). One study comparing the amino acid sequence of ET-1 in dogs and cats concluded that ET-1 is identical in dogs, humans, mice and rats; however, there is a single amino acid change at position seven in ET-1 of cats (BIONDO et al., 2003). The application of a human ELISA assay in cats, which uses an amino acid sequence that is identical in both species and shows differences in ET-1 plasma values between healthy cats, cats suffering from hypertrophic cardiomyopathy (HCM) and cats suffering from hypertrophic cardiomyopathy (HCM) and $\mathrm{CHF}$, was validated in 2004 (PROSEK et al., 2004).

HCM is a disease characterized by left ventricular hypertrophy albeit without dilation of the ventricular chamber in the absence of another cardiac or systemic disease, which, by itself, causes obvious hypertrophy (FOX; LIU; MARON, 2005). Maine Coon cats may be affected by familial HCM (KITTLESON et al., 1999), whose transmission is related to cardiac myosin binding protein $\mathrm{C}$ (MYBPC3) gene mutations (MEURS et al., 2005). Few studies exist in the literature analyzing ET-1 in felids. Currently, further studies in feline patients are required to clarify the true meaning of the increased plasma concentration of endothelin in cats suffering from HCM (BOSWOOD, 2004). The aim of this study was to assess the ET-1 values in healthy Maine Coon cats.

\section{Materials and Methods}

This study was performed between March 2011 and November 2011 at the Cardiology Unit (Serviço de Cardiologia) in the Department of Internal Medicine (Departamento de Clínica Médica, VCM) of the Veterinary Hospital (Hospital Veterinário, HOVET) at the School of Veterinary Medicine and 
Animal Science of the University of São Paulo (Faculdade de Medicina Veterinária e Zootecnia da Universidade de São Paulo, FMVZ-USP), at the Clinical Laboratory of the VCM/HOVET/ FMVZ/USP, at Genese Institute of Scientific Analysis (Instituto Gênese de Análises Cientificas), at PROVET Laboratory of Hormone Testing Institute of Diagnoses and Specialities (Laboratório de Dosagens Hormonais PROVET - Instituto de Diagnósticos e Especialidades) and at Veterinary Cardiac Genetics Laboratory at Washington State University. The Maine Coon cats used in this study were originally from breeders informed about the research study proceedings, who signed a consent and commitment form. The study was approved by the Ethics Committee on animal use at FMVZ-USP.

The animals were selected regardless of gender and age considering the following exclusion criteria: medication used including angiotensinconverting enzyme inhibitors (ACEi), calcium channel blockers and diuretics; total $\mathrm{T}_{4}\left(\mathrm{~T}_{4}\right)$ and plasma creatinine concentrations above $3.9 \mu \mathrm{g} /$ dL (SAMPEDRANO et al., 2009) and $2.17 \mathrm{mg} /$ dL (REYNOLDS et al., 2010), respectively; systolic blood pressure (SBP) measurements were performed by ultrasonic Doppler method (Vascular Doppler DV610B, Medmega, Franca, SP) with a forelimb cuff (BROWN et al., 2007) and the normal range of SBP in cats was below $160 \mathrm{mmHg}$ (STEPIEN, 2011); positive animals for mutations in the MYBPC3 gene; and presence of congenital heart disease and/or cardiac hypertrophy diagnosed by conventional echocardiography. Left ventricular hypertrophy was assessed through M-mode echocardiographic examination where the thickness of the left ventricular free wall and/or the ventricular septum in diastole was greater than $6 \mathrm{~mm}$ (FOX; LIU; MARON, 1995).
Blood samples were collected from animals fasting for eight to 12 hours by jugular venipuncture and were stored in tubes with BD gel separator. Immediately after collection, the blood tubes were left standing for approximately 20 minutes on ice in a Styrofoam box (internal temperature of approximately $+20^{\circ} \mathrm{C}$ ) and then centrifuged at 3,000 rpm at $+4^{\circ} \mathrm{C}$ for eight minutes (Sorvall Legend RT refrigerated centrifuge). The samples showing lipemia and/or hemolysis were discarded. Sera were aliquoted into $600 \mu \mathrm{L}$ Axygen microcentrifuge tubes and were stored in a freezer at a temperature of approximately $-80^{\circ} \mathrm{C}$ for up to eight months. Serum creatinine and $\mathrm{T}_{4}$ quantifications were performed on blood from the sample collection.

Microcentrifuge tubes were transported in Styrofoam boxes containing dry ice because the endothelin assays were performed by a third-party laboratory at the Genese Institute of Scientific Analyses (Instituto Gênese de Análises Cientificas). Samples were thawed and kept at room temperature immediately prior to performing the assay using the Endothelin (1-21) ELISA kit for humans (Biomedica Gruppe, Vienna, Austria). The assay was performed following instruction provided by the manufacturer then aprotinin was not utilized in the present study. The choice of kit was based on the validation performed by Prosek et al. (2004). The plate readings were performed using automatic reader (Awareness Technology Inc. Stat Fax 2100). The ET-1 detection range was between 0.31 and $20.00 \mathrm{fmol} / \mathrm{mL}$ with a threshold of $0.02 \mathrm{fmol} / \mathrm{mL}$. The analytical standard curve for each assay was generated by using the ET-1 standard provided in the kit but adding two other dilutions based on a 1:1 dilution of the first concentration and a doubling of the final concentration $(0.3125 / 0.625 / 1.25 / 2.5 / 5 /$ $10 / 20 \mathrm{fmol} / \mathrm{mL}$ ) (Figure 1). 
Figure 1. Curve analysis pattern designed for testing the Biomedica Endothelin (1-21) diagnosis kit- Sao Paulo, 2012.

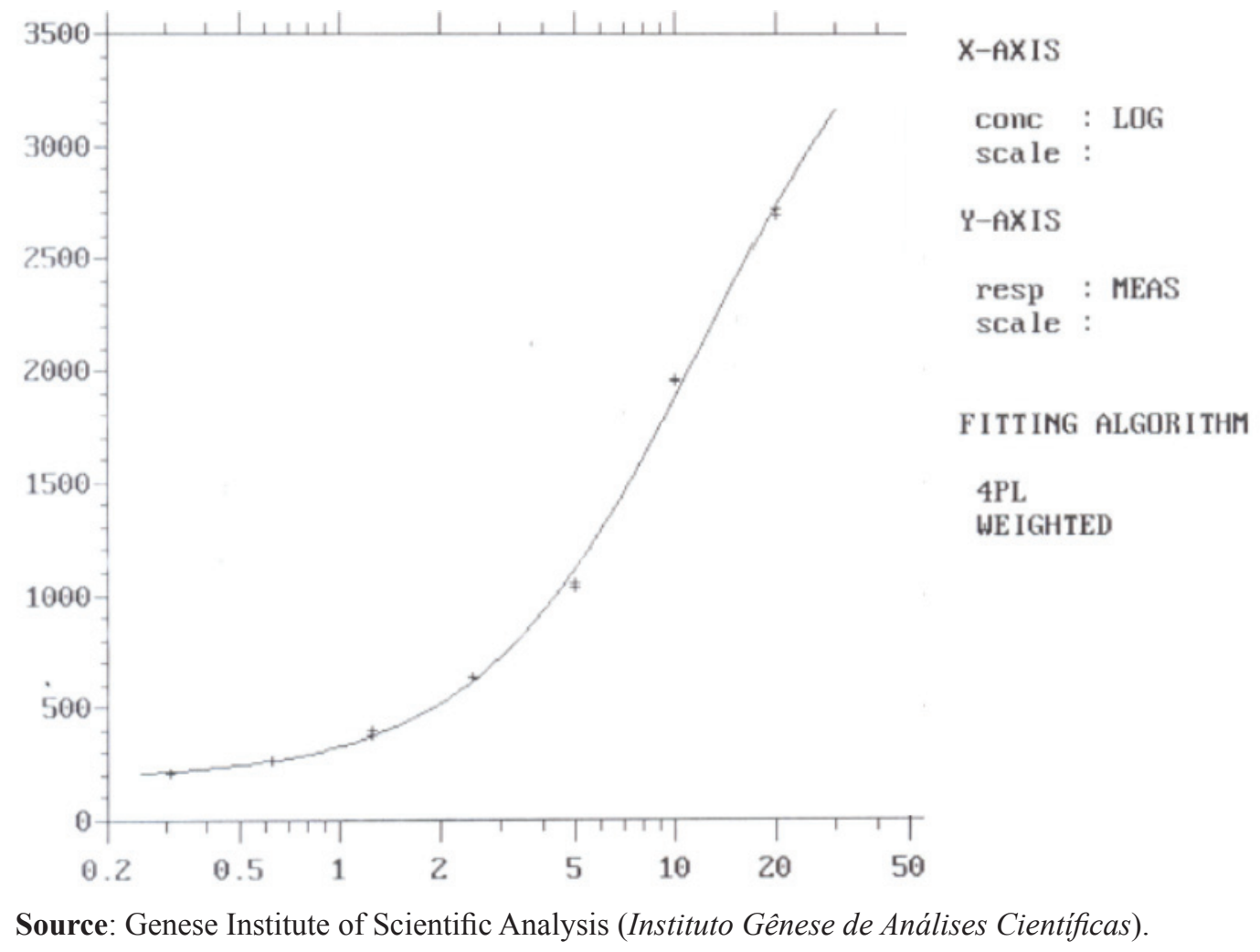

The echocardiogram was performed by using the Vivid 7 Expert echocardiograph (Vivid 7, GE Vingmed Ultrasound AS, Horten, Norway). Echocardiographic examinations were performed according to the American Society of Echocardiography (ASE) recommendations (BOON, 1998). The M-mode parameters evaluated were as follows: thickness of the interventricular septum in diastole (IVSd); thickness of the left ventricular free wall in diastole (LVWd); internal diameter of the left ventricular cavity in diastole (LVDd); internal diameter of the cavity of the left ventricle in systole (LVDs); fractional shortening (FS); heart rate (HR); aortic root (Ao); left atrium (LA); ratio between the aortic root and left atrium measurements (Ao/LA). Three measurements were performed for each echocardiographic parameter, and the mean of the three values was considered for analysis. Furthermore, we attempted to minimize interference caused by breathing, motion of the

heart within the thorax and changes in cardiac filling pressure (BOON, 1998).

A statistical summary of the mean, standard deviation (SD), median (Med) and interquartile range (IQR) of the echocardiographic measurements as well as the levels of $\mathrm{T}_{4}$, creatinine, SBP and ET-1 was compiled (MINITAB ${ }^{\circledR}$ Release 14.12.0).

\section{Results}

A total of 38 healthy MC cats were evaluated, 13 males (34.2\%) and 25 females (65.8\%) including seven castrated males (53.85\%) and 17 spayed females $(68 \%)$. The mean age of the animals was $40.6 \pm 21.59$ months (ranging from 9 to 114 months). The mean weight of the animals was $6.18 \pm 1.52 \mathrm{~kg}$ (ranging from 3.4 to $7.5 \mathrm{~kg}$ ). Results about M-mode echocardiographic values, SBP, $\mathrm{T}_{4}$ and creatinine serum levels are show with mean, SD, Med and IQR as well as their reference rangers are shown in Table 1. 
Table 1. Mean, standard deviation (SD), median (Med) and interquartile range (IQR) of echocardiographic measurements, T4, creatinine and SBP - Sao Paulo, 2012.

\begin{tabular}{|c|c|c|c|}
\hline Parameter & Values & Parameter & Values \\
\hline IVSd (cm) & & HR (bpm) & \\
\hline Mean (SD) & $0.423(0.052)$ & Mean (SD) & $205.92(26.64)$ \\
\hline Med (IQR) & $0.425(0.38 ; 0.463)$ & Med (IQR) & $203.5(189 ; 226.5)$ \\
\hline LVWd (cm) & & Ao (cm) & \\
\hline Mean (SD) & $0.43(0.058)$ & Mean (SD) & $1.04(0.12)$ \\
\hline Med (IQR) & $0.43(0.40 ; 0.47)$ & Med (IQR) & $1.01(0,95 ; 1.13)$ \\
\hline Septum/wall ratio & & LA (cm) & \\
\hline Mean (SD) & $0.989(0.095)$ & Mean (SD) & $1.32(0.14)$ \\
\hline Med (IQR) & $0.989(0.933 ; 1.051)$ & Med (IQR) & $1.28(1.19 ; 1.46)$ \\
\hline LVDd (cm) & & Ao/LA & \\
\hline Mean (SD) & $1.55(0.22)$ & Mean (SD) & $0.79(0.09)$ \\
\hline Med (IQR) & $1.54(1.38 ; 1.74)$ & Med (IQR) & $0.784(0.75 ; 0.84)$ \\
\hline LVDs (cm) & & SBP (mmHg) & \\
\hline Mean (SD) & $0.738(0.192)$ & Mean (SD) & $128.4(15)$ \\
\hline Med (IQR) & $0.700(0.625 ; 0.845)$ & Med (IQR) & $129.0(118.5 ; 140)$ \\
\hline LVEF (\%) & & $\mathrm{T}_{4}(\mathrm{ug} / \mathrm{dL})$ & \\
\hline Mean (SD) & $85,64(7.25)$ & Mean (SD) & $1.79(0.52)$ \\
\hline Med (IQR) & $85.97(81.54 ; 92,11)$ & Med (IQR) & $1.67(1.42 ; 2.09)$ \\
\hline FS (\%) & & $\mathrm{C}(\mathrm{mg} / \mathrm{dL})$ & \\
\hline Mean (SD) & $52.79(8.88)$ & Mean (SD) & $1.48(0.26)$ \\
\hline Med (IQR) & $51.77(46.83 ; 60.36)$ & Med (IQR) & $1.5(1.28 ; 1.7)$ \\
\hline
\end{tabular}

Source: Elaboration of the authors.

ET-1 serum concentration in 38 healthy MC cats was $21.4 \pm 9.6 \mathrm{fmol} / \mathrm{mL}$. The values for the measurements of ET-1 for each animal are shown in Table 2. 
Table 2. Serum concentrations of ET-1 from each animal - Sao Paulo, 2012.

\begin{tabular}{cccc}
\hline Animal & Serum concentrations of ET-1 $(\mathrm{fmol} / \mathrm{mL})$ & Animal & Serum concentrations of ET-1 $(\mathrm{fmol} / \mathrm{mL})$ \\
\hline 1 & 23.316 & 20 & 26.685 \\
2 & 21.437 & 21 & 26.878 \\
3 & 29.575 & 22 & 31.217 \\
4 & 7.443 & 23 & 28.271 \\
5 & 30.507 & 24 & 29.35 \\
6 & 31.582 & 25 & 30.683 \\
7 & 11.939 & 26 & 28.565 \\
8 & 31.732 & 27 & 27.727 \\
9 & 33.913 & 28 & 5.316 \\
10 & 9.639 & 29 & 13.169 \\
11 & 6.997 & 30 & 10.384 \\
12 & 7.167 & 31 & 25.853 \\
13 & 20.347 & 32 & 8.622 \\
14 & 20.981 & 33 & 27.705 \\
15 & 31.722 & 34 & 32.224 \\
16 & 12.124 & 35 & 4.15 \\
17 & 19.62 & 36 & 9.685 \\
18 & 29.944 & 37 & 20.254 \\
19 & 16.625 & 38 & 29.417
\end{tabular}

Source: Elaboration of the authors.

\section{Discussion}

Unfortunately, the ET-1 values could not be assessed in the present study because lower ET-1 values were expected based on the results reported by another study (PROSEK et al., 2004). However, the ET-1 values of $21.4 \pm 9.6 \mathrm{fmol} / \mathrm{mL}$ for the mean and SD and $24.58 \mathrm{fmol} / \mathrm{mL}(11.55 ; 29.67)$ for the med and IQR were derived based on the analytical standard curve (Figure 1). These values are beyond the mean value of the ET-1 plasma concentration reported by Prosek et al. (2004) in healthy cats, which was $0.777 \mathrm{fmol} / \mathrm{mL}$.

No serine protease inhibitor enzymes such as aprotinin were used in the present study based on the instructions by the manufacturer (Biomedica), which is in contrast to the report by Prosek et al. (2004). However, the ET-1 values in our study were higher than the ET-1 values found by Prosek et al. (2004), and our ET-1 values were higher than the assay sensitivity threshold. The values were approximately one decimal point above those described by Prosek et al. (2004). Upon request, the manufacturer indicated that the antibody used in our study was identical to the one used in the study by Prosek et al. (2004), although technical changes had occurred, which could explain the difference in assay sensitivity. The use of serine protease inhibitors such as aprotinin remains controversial among researchers even for the measurement of natriuretic peptides such as N-terminal prohormone of brain natriuretic peptide (NT-proBNP). According to Ettinger et al. (2012), the analysis of NT-proBNP requires a mix of protease inhibitors, whereas Wess et al. (2011) do not use protease inhibitors. Mueller et al. (2004) performed a study comparing the serum concentration of brain natriuretic peptide (BNP) and NT-proBNP at various times after freezing the samples without using serum protease inhibitor 
and concluded that freezing considerably affects the concentrations assessed when using BNP, while there was no significant difference in NTproBNP concentrations before and after freezing and thawing at $-20^{\circ} \mathrm{C}$ for up to four months. The use of aprotinin does not appear to be relevant for preserving ET-1, which is similar to NT-proBNP because the ET-1 serum levels found in the present study are higher than the plasma values found by Prosek et al. (2004).

In the present study, cat serum was obtained from blood centrifugation in tubes with a gel separator, whereas Prosek et al. (2004) used plasma obtained from centrifugation in tubes containing ethylene diaminetetraacetic acid (EDTA). We decided to use serum because the manufactory instruction refers that measurement maybe done using serum, plasma, urine or cell culture supernatants. This difference in protocol could be another explanation for the discrepancy in ET-1 values. Although the National Academy of Clinical Biochemistry (WU et al., 1999) recommends performing cardiac marker measurement using plasma, some studies have shown higher cardiac troponin measurements in serum fractions relative to plasma fractions from the same blood samples (GERHARDT et al., 2000). The relationship between troponins and heparin remains unclear. Although the formation of a complex that impairs the adhesion of antibodies to commercial assays appears to occur in human blood (ERIKSSON et al., 2003), the gel separator does not seem to affect the adhesion of troponins (GERHARDT et al., 2000). A similar fact may occur with endothelin based on our results, which could explain the higher ET-1 values we found.

In the present study we used just serum samples without aprotinin for ET-1 measurements, so we can not confirm that high values we found can be justified by difference between the samples nature (serum/ plasma) or by absence of use of aprotinin, although, currently, the use of aprotinin is not indicated by manufacturer assay instruction.
Further studies on ET-1 are understandably required based on the results found because ET-1 theoretically has great potential as a cardiac marker (BOSWOOD, 2004). The method of sample collection for ET-1 analysis should first be understood regarding the use of serum protease inhibitors as well as differences between the serum and plasma concentrations of ET-1. However, ET-1 quantification in serum from Maine Coon cats using the Biomedica Endothelin (1-21) diagnosis assay requires a 1:20 dilution of samples considering the fact that the ET- 1 values in cats with HCM and/or CHF may be up to five times the values found in healthy cats according to Prosek et al. (2004).

\section{Conclusions}

ET-1 serum measurements $(21.4 \pm 9.6 \mathrm{fmol} / \mathrm{mL})$ without aprotinin in healthy MC cats is greater than values ET-1 plasma concentration with aprotinin reported by Prosek et al. (2004) in healthy cats $(0.777 \mathrm{fmol} / \mathrm{mL})$, using the same Biomedica Endothelin (1-21) diagnosis kit. Using this kit for serum ET-1 measurements without aprotinin in MC cats the dilution of samples is necessary.

\section{Ethics Committee}

This study was approved by the Ethics Committee on animal use at the School of Veterinary Medicine and Animal Science at the University of São Paulo (Faculdade de Medicina Veterinária e Zootecnia da Universidade de São Paulo) under protocol No. 2010/2010, on 09/29/2010.

\section{Acknowledgments}

The authors thank the São Paulo Research Foundation (FAPESP) for funding the research study (process No. 09/54251-9) and for granting the MSc. scholarship (process No. 10/02317-3). 


\section{References}

BIONDO, A. W.; EHRHARTZ, E. J.; SISSON, D. D.; BULMER, B. J.; DE MORAIS, H. A. A.; SOLTER, P. F. Immunohistochemistry of atrial and brain natriuretic peptides in control cats and cats with hypertrophic cardiomyopathy. Veterinary Pathology, Cary, v. 40, n. 5, p. 501-506, 2003.

BOON, J. A. Manual of veterinary echocardiography. Baltimore: Williams \& Wilkins, 1998. 478 p.

BOSWOOD, A. Editorial: the rise and fall of the cardiac biomarker. Journal of Veterinary Internal Medicine, Malden, v. 18, n. 6, p. 797-799, 2004.

BROWN, S.; ATKINS, C.; BAGLEY, R.; CARR, A.; COWGILL, L.; DAVIDSON, M.; EGNER, B.; ELLIOTT, J.; HENIK, R.; LABATO, M.; LITTMAN, M.; POLZIN, D.; ROSS, L.; SNYDER, P.; STEPIEN, R. Guidelines for the identification, evaluation, and management of systemic hypertension in dogs and cats. Journal of Veterinary Internal Medicine, Malden, v. 21, n.3, p. 542-558. 2007.

ERIKSSON, S.; JUNIKKA, M.; LAITINEN, P.; MAJAMAA-VOLTTI, K.; ALFTHAN, H.; PETTERSSON, K. Negative interference in cardiac troponin I immunoassays from a frequently occurring serum and plasma component. Clinical Chemistry, Washington, v. 49, n. 7, p. 1095-1104, 2003.

ETTINGER, S. J.; FARACE, G.; FORNEY, S.D.; FRYE, M.; BEARDOW, A. Evaluation of plasma N-terminal pro-B-type natriuretic peptide concentrations in dogs with and without cardiac disease. Journal of the American Animal Hospital Association, Denver, v. 240, n. 2, p. 171-180, 2012.

FOX, P. R.; LIU, S-K.; MARON, B. J. Echocardiographic assessment of spontaneously occurring feline hypertrophic cardiomyopathy: an animal model of human disease. Circulation, Dallas, v. 92, n. 9, p. 26452651, 1995.

GERHARDT, W.; NORDIN, G.; HERBERT, A. K.; BURZELL, B. L.; ISAKSSON, A.; GUSTAVSSON, E.; HAGLUND, S.; MÜLLER-BARDORFF, M.; KATUS, H. A. Troponin T and I assays show decreased concentrations in heparin plasma compared with serum: lower recoveries in early than in late phases of myocardial injury. Clinical Chemistry, Washington, v. 46, n. 6, p. 817-821, 2000.

KITTLESON, M. D.; MEURS, K. M.; MUNRO, M. J.; KITTLESON, J. A.; LIU, S. K.; PION, P. D.; TOWBIN, J. A. Familial hypertrophic cardiomyopathy in Maine Coon cats: an animal model of human disease. Circulation, Dallas, v. 99, n. 24, p. 3172-3180, 1999.
LEVIN, E. R. Endothelins. The New England Journal of Medicine, Waltham, v. 333, n. 6, p. 356-363, 1995.

MCMURRAY, J.; RAY, S. G.; ABDULLAH, I.; DARGIE, H. J.; MORTON, J. J. Plasma endothelin in chronic heart failure. Circulation, Dalas, v. 85 , n. 4, p. 1374-1379, 1992.

MEURS, K. M.; SANCHEZ, X.; DAVID, R. M.; BOWLES, N. E.; TOWBIN, J. A.; REISER, P. J.; KITTLESON, J. A.; MUNRO, M. J.; DRYBURGH, K.; MCDONALD, K. A.; KITTLESON, M. D. A cardiac myosin binding protein $\mathrm{C}$ mutation in the Maine Coon cat with familial hypertrophic cardiomyopathy. Human Molecular Genetics, Oxford, v. 14, n. 23, p. 3587-3593, 2005.

MUELLER, T.; GEGENHUBER, A.; DIEPLINGER, B.; POELZ, W.; HALTMAYER, M. Long-term stability of endogenous B-type natriuretic peptide (BNP) and amino terminal proBNP (NT-proBNP) in frozen plasma samples. Clinical Chemistry and Laboratory Medicine, Berlin, v. 42, n. 8, p. 942-944, 2004.

PROSEK, R.; SISSON, D. D.; OYAMA, M.; BIONDO, A. W.; SOLTER, P. F. Measurements of plasma endothelin immunoreactivity in healthy cats and cats with cardiomyopathy. Journal of Veterinary Internal Medicine, Malden, v. 18, n. 6, p. 826-830, 2004.

REYNOLDS, B. S.; CONCORDET, D.; GERMAIN, C. A.; DASTE, T.; BOUDET, K. G.; LEFEBVRE, H. P. Breed dependency of reference intervals for plasma biochemicalvalues in cats. Journal of Veterinary Internal Medicine, Malden, v. 24, n. 4, p. 809-818, 2010.

SAMPEDRANO, C. C.; CHETBOUL, V.; MARY, J.; TISSIER, R.; ABITBOL, M.; SERRES, F.; GOUNI, V.; THOMAS, A.; POUCHELON, J. -L. Prospective echocardiographic and tissue Doppler imaging screening of a population of Maine Coon cats tested for the A31P mutation in the myosin-binding protein $\mathrm{C}$ gene: a specific analysis of the heterozygous status. Journal of Veterinary Internal Medicine, Malden, v. 23, n. 1, p. 91-99, 2009.

SELVAIS, P. L.; ROBERT, A.; AHN, S.; LINDEN, F. V.; KETELSLEGERS, J. M.; POULEUR, H.; ROUSSEAU, M. F. Direct comparison between endothelin-1, $\mathrm{N}$-terminal proatrial natriuretic factor, and brain peptide as prognostic markers of survival in congestive heart failure. Journal of Cardiac Failure, Chevy Chase, v. 6, n. 3, p. 201-207, 2000.

STEPIEN, R. L. Feline systemic hypertension: diagnosis and management. Journal of Feline Medicine and Surgery, Thousand Oaks, v. 13, n. 1, p. 35-43, 2011.

WESS, G.; DAISENBERGER，P.; MAHLING，M.; HIRSCHBERGER, J.; HARTMANN, K. Utility of 
measuring plasma $\mathrm{N}$-terminal pro-brain natriuretic peptide in detecting hypertrophic cardiomyopathy and differentiating grades of severity in cats. Veterinary Clinical Pathology, Madison, v. 40, n. 2, p. 237-244, 2011.

WU, A. H.; APPLE, F. S.; GIBLER, W. B.; JESSE, R. L.; WARSHAW, M. M.; VALDES JUNIOR, R. National academy of clinical biochemistry standards of laboratory practice: recommendations for the use of cardiac markers in coronary artery. Clinical Chemistry, Washington, v. 45, n. 7, p. 1104-1121, 1999.

YANAGISAWA, M.; KURIHARA, H.; KIMURA, S.; TOMOBE, Y.; KOBAYASHI, M.; MITSUI, Y.; YAZAKI, Y.; GOTO, K.; MASAKI, T. A novel potent vasoconstrictor peptide produced by vascular endothelial cells. Nature, London, v. 332, n. 31, p. 415, 1988. 
